\title{
IMPROVING STUDENTS' SPEAKING SKILL THROUGH VIDEO DUBBING
}

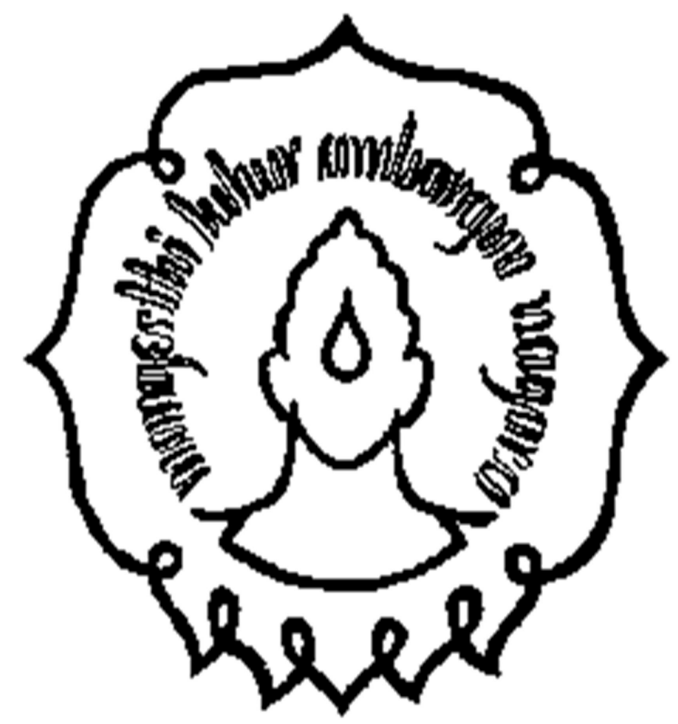

A THESIS ARTICLE

Vivy Zuny Mandasari

K2210084

Submitted to Teacher Training and Education Faculty of Sebelas Maret University to Fulfill One of the Requirements for Getting the Undergraduate Degree of Education in English

ENGLISH EDUCATION DEPARTMENT

TEACHER TRAINING AND EDUCATION FACULTY

SEBELAS MARET UNIVERSITY

2014 


\title{
Improving Students' Speaking Skill Through Video Dubbing
}

\author{
Vivy Zuny Mandasari, Dewi Rochsantiningsih, Teguh Sarosa \\ English Education Department of Teacher Training and Education Faculty \\ Sebelas Maret University \\ e-mail: vivyzuma@gmail.com
}

\begin{abstract}
The purposes of this research are to identify: (1) whether and to what extent the use of VD improve students' speaking skill, and (2) the strengths and the weaknesses of $V D$ when implemented in this research. This research use classroom action research method. The subject of this research is class X-5 of SMA $N$ Kebakkramat Karanganyar in 2013/2014 academic year. The techniques of collecting data are observation, diary, interview, questionnaire, document analysis, and test. The techniques of collecting data are Constant Comparative Method (CCM) and statistic descriptive. Based on the research findings, students' achievement on grammar, vocabulary, fluency, pronunciation, and content improved. Students' attitude change from ignoring becomes paying attention. Furthermore, weaknesses were indicated that although students have many oral practices, they still produce unacceptable pronunciation. The second weakness is that some students are still awkward in using $V D$ so that they need some help and guidance. For further research, other researcher could focus on the other skills like listening, reading, and writing or on the attitude improvement such as motivation, participation, and so on.

Key Words: Students' Speaking Skill, Video Dubbing, Classroom Action Research
\end{abstract}

\footnotetext{
ABSTRAK

Tujuan penelitian ini adalah mengidentifikasi: (1) apa dan dalam aspek apa saja penggunaan VD dapat meningkatkan kemampuan berbicara siswa, dan (2) kelebihan dan kelemahan dari VD ketika diimplementasikan di dalam penelitian ini. Penelitian ini menggunakan metode penelitian tindakan kelas. Subyek penelitian adalah kelas X5 SMA N Kebakkramat Karanganyar tahun ajaran 2013/2014. Teknik pengumpulan data adalah observasi, diari, wawancara, kuesioner, analisis dokumen, dan tes. Teknik analisis data menggunakan Metode Konstan Komparatif (MKK) dan deskriptif statistic. Berdasarkan temuan penelitian, prestasi siswa dalam indikator tata bahasa, kosa kata, kelancaran, pengucapan, dan konten meningkat. Sikap siswa berubah dari mengabaikan menjadi memperhatikan. Lebih jauh lagi, terindikasi kelemahan bahwa meskipun siswa telah banyak berlatih, siswa masih menghasilkan pengucapan yang tidak dapat diterima (tidak sesuai dengan seharusnya). Kelemahan kedua adalah beberapa siswa masih merasa kikuk menggunakan VD sehingga mereka masih membutuhkan bantuan dan bimbingan. Untuk penelitian lebih jauh, peneliti lain dapat memfokuskan pada kemampuan lain seperti mendengarkan, membaca, dan menulis atau pada peningkatan sikap seperti motivasi, partisipasi, dan sebagainya. Kata Kunci: Kemampuan Berbicara Siswa, Video Dubbing, Penelitian Tindakan Kelas
} 
Kayi's (2006) stated that "speaking is a crucial part of second language learning and teaching”. Despite its importance, language include speaking is taught monotonously in the previous. Traditional language teaching is based on a traditional approach to the target language, which regards the language as a body of grammatical rules and an enormous number of words that are combined according to the rules. Traditional methodology thus focuses on grammatical structures and isolated items of vocabulary (Boumova, 2008).

Teaching approach, method, and technique have been developed well. They change from traditional to modern, from passive to active, from teacher centered to student-centered, and so on. Because of the teaching era development, teachers and/or researchers make some new formula and also use varies media of learning to conduct a lesson better than before. In addition, English standard score is 70 based on National Education Department in Arifin (2012).

Pre research in the first grade of SMA N Kebakkramat found that there are some indicators of the students' low speaking skill, such as: (1) poor grammar, (2) limited vocabularies, (3) inability to understand what they learn and they speak that makes the content of students' speeches cannot be caught, (4) inability to speak fluently, and (5) mispronouncing English words.

Based on the pre research result, I proposed a solution to solve the problem. I offer Video Dubbing to be implemented in class in order to improve students' speaking skill. I believe that Video Dubbing can be applied in the first grade of SMA N Kebakkramat Karanganyar. According to Burston (2005), Video Dubbing 
offers an excellent opportunity to develop the skills of foreign language, especially speaking learner at all linguistic levels.

Video Dubbing is one of modern teaching technique. Traditional and modern teaching methods are two different terms. In modern one, teacher should be creative and innovative (Winarko, 2012). The method of film dubbing (in this context, it is the same term as video dubbing) offers a unique opportunity for the imitation of English pronunciation and intonation with in a contextualized scenario (Chiu, 2011).

This research aimed to identify: (1) whether and to what extent the use of VD improve students' speaking skill, and (2) the strengths and the weaknesses of VD when implemented in this research.

Speaking happens in real time; usually the person you are talking to is waiting for you to speak right then. Second, when you speak, you cannot edit and revise what you wish to say, as you can if you are writing (Herminda, 2013). Speaking is many things - it is thinking of what one wishes to say, choosing the right words from our vocabulary, putting the words in the proper grammatical framework, communicating the feelings we have, and so on. At one level though, speaking is producing movements: movements of the rib cage, the vocal cords, and the mouth. To make these movements, we must control the activity of about 100 muscles. One thing about stuttering is very clear: when disfluency occurs, Individual who stutters is not able to appropriately control the activity of the many muscles involved in speech (Smith, 2005). 
From the definitions above, it can be constructed that speaking is one or two or more directions of oral process to convey something which contains of word, phrase, or sentence grammatically or not. Since speaking is oral activity, it is natural to make mistake without revise it before conveying it publicly. Speaking in two or more directions needs feedback from the one(s) who is (are) talking to.

Video dubbing is not a new term in this time. Video dubbing is one of methods to make people understanding more about the video content. It can be used freely in this time since its simplicity and understandable operation through Windows Movie Maker. In order to reach the goal of the speaking skill improvement, students are involved in many activities of Video Dubbing.

Film dubbing utilizes authentic film clips, with which learners dub the voices of muted characters (Chiu, 2011). In the same line, Burston (2005: 80-81) stated that the more modest activity of video dubbing, that is, the simple substitution of the soundtrack of an existing video, offers essentially the same pedagogical benefits of full video production with substantially less investment of time and effort. At its simplest, it need only involve substituting student voices for an existing soundtrack.

Based on the theory, I could make a construct that Video Dubbing is revoicing a video from the original voice to the other one.

\section{RESEARCH METHODS}

This research was carried out in class X-5 of SMA N Kebakkramat Karanganyar in the second semester of the academic year 2013/2014. The time of the research was from April 24 to May 23, 2014. 
This research design is classroom action research. Based on Mettetal (2001), Classroom Action Research is a method of finding out what works best in your own classroom so that you can improve student learning. The model of classroom action research is planning, acting, observing, and reflecting (Arikunto, 2007: 09) which is considered too as the CAR cycle based on Kemmis and McTaggart (2007: 278). The reasons of choosing CAR are because this researcher can be set within a specific context or situation, researchers can be participants, action research involves continuous evaluation and modifications, there are opportunities for theory to emerge, the study can lead to open-ended outcomes, and through action research, researcher can bring a story to life (Koshy, 2005: 21).

The techniques of collecting data are observation, questionnaire, interview, document analysis, and test. There are two kinds of data in this research; such as qualitative and quantitative data. The qualitative data are analyzed by Constant Comparative Method (CCM). According to Glaser (2008), there are four stages of the constant comparative method: (1) comparing incidents applicable to each category, (2) integrating categories and their properties, (3) delimited the theory, and (4) writing the theory which all of the stages are used in this research.

I use Descriptive Statistic (DS) in quantitative data analysis. Jaggi (1) stated that DS gives numerical and graphic procedures to summarize a collection of data in a clear and understandable way. Descriptive statistics help us to simplify large amounts of data in a sensible way. Each descriptive statistic reduces lots of data into a simpler summary. 


\section{RESEARCH FINDINGS AND DISSCUSSION}

Pre research activities were held in order to know the condition of the class.

I conducted observation in the subject class, interviews to the teacher and three students from the class, a skill polling, and a questionnaire to analyze students' speaking problems. After pre research activities, I conducted pre test to measure the students' speaking skill before the action. The summary of pre research was stated on the table 1.

Table 1. Summary of Pre Research

\begin{tabular}{lllr}
\hline Technique & Result & Data \\
\hline Observation & -there was no speaking class in English lesson except & Field notes and \\
& reading aloud text correction. & Research Diary \\
& -teacher told too much story during the lesson. \\
& -teacher used direct correction when students were & \\
& mistaken in reading aloud. & \\
& -students got some difficulties in speaking. & \\
& -students were passively involved in English class. & \\
Interview & -students said that they never got any speaking class. & Interview Scripts \\
& -the teacher told that he usually calls students' name & \\
& to make them speak. & \\
Questionnaire & -students wanted to have better speaking class. & \\
& -all students like English. & Questionnaire \\
& -students found some difficulties in speaking. & Analysis \\
Test & The average students' score was 58.75. & Pre test score \\
\hline
\end{tabular}

Table 1 shows the result of pre research activities. It indicates the problem in the class that students actually like English, but they have lack of ability in speaking. Moreover, students also want to have speaking activity in class. In fact, the teacher has not conducted any speaking class. The teacher stated out of the interview record that he only gave the students speaking score by $\mathrm{T}$ (True) or $\mathrm{F}$ (False) after calling some students to come forward to read aloud a text without considering the focus skill in the English class. Hence, students' speaking skill needs to be improved. 
I did some procedures in every cycle. First, I planned the action by making lesson plan, material, and list of activities. Those plans were arranged based on the technique implemented, video dubbing. After that, all of the preparations were implemented in the class. I took an observation in the class during the action. From the result of the observation, it could be concluded that there were several points should be evaluated and reflected.

The action was implemented into two cycles which there was such improvement in each one. In test 1 , students got 7.88 points of score improvement from pre test. In test 2 , students' achievement improved 8.40 points from test 1 . The detail improvement was listed in table 2.

Table 2. Improvement of Speaking Achievement

\begin{tabular}{ccc}
\hline Test & Mean Score & Improvement \\
\hline Pre test & 58.75 & \\
Test 1 & 66.63 & 7.88 \\
Test 2 & 75.03 & 8.40 \\
\hline
\end{tabular}

The detail indicator score improvement from pre test, test 1 , and test 2 which contained grammar, vocabulary, content, fluency, and pronunciation was shown in table 3.

Table 3. Summary of Indicator Improvement

\begin{tabular}{lccccc}
\hline & Grammar & Vocabulary & Content & Fluency & Pronunciation \\
\hline Pre test & 55.7 & 57.7 & 64.3 & 58.3 & 58 \\
Test 1 & 62 & 67.7 & 74.6 & 65.2 & 62 \\
Improvement 1 & 6.3 & 10 & 12.3 & 6.9 & 4 \\
\hline Test 2 & 68.5 & 78 & 83.8 & 76.6 & 68 \\
Improvement 2 & 6.5 & 10.3 & 9.2 & 10.4 & 6 \\
\hline Total Improvement & 12.8 & 20.3 & 21.5 & 17.3 & 10 \\
\hline
\end{tabular}

Table 4 shows the improvement of each test. This could be concluded that step by step, the use of VD activities could affect students' achievement by time. The improvement of the speaking score is measured by some indicators, such as; 
grammar, vocabulary, content, fluency, and pronunciation. The explanation of the improvement based on the indicators which are used in this research is shown in table 4 .

Table 4. Improvement of Students' Speaking Skill 2

\begin{tabular}{lll}
\hline The condition before implementing the action & The condition after implementing the action \\
\hline 1) $\begin{array}{l}\text { Students produced many wrong sentences } \\
\text { in their speech. }\end{array}$ & 1) $\begin{array}{l}\text { Students could produce grammatical } \\
\text { sentences in their speech. }\end{array}$ \\
2) $\begin{array}{l}\text { Students repeated the same words in many } \\
\text { expressions }\end{array}$ & 2) $\begin{array}{l}\text { Students got many new vocabularies to } \\
\text { express some different expressions }\end{array}$ \\
3) $\begin{array}{l}\text { Students could not make the cohesive and } \\
\text { correlative between one to another }\end{array}$ & 3) $\begin{array}{l}\text { Students could make the cohesive and } \\
\text { correlative sentences in conveying the } \\
\text { content }\end{array}$ \\
$\begin{array}{ll}\text { sentences and paragraphs } \\
\text { 4) Students produced many stops and fillers } \\
\text { during their speech }\end{array}$ & 4) $\begin{array}{l}\text { Students could reduce the stops and the } \\
\text { fillers during their speech }\end{array}$ \\
5) Students pronounced many English words & 5) $\begin{array}{l}\text { Students could reduce their } \\
\text { mispronunciations of some words. }\end{array}$ \\
wrongly &
\end{tabular}

Besides, the students' attitude in class was better than the previous. Their attitude changed from ignoring to caring. The class became active and alive. The detail improvement in the class is stated in table 7

Table 5. Improvement of Class Situation

\begin{tabular}{|c|c|}
\hline Class situation before implementing the action & Class situation after implementing the action \\
\hline $\begin{array}{l}\text { 1) Most students were chitchatting with their } \\
\text { friends and sometimes paid attention only to } \\
\text { the interesting picture in the slide. }\end{array}$ & $\begin{array}{l}\text { 1) Some students paid attention to the } \\
\text { explanation. }\end{array}$ \\
\hline $\begin{array}{l}\text { 2) Some students did not answer teacher's } \\
\text { question directly. They were afraid to talk in } \\
\text { front of their friends. }\end{array}$ & $\begin{array}{l}\text { 2) Students who were asked to answer the } \\
\text { question could directly respond as their } \\
\text { own capability of answering }\end{array}$ \\
\hline $\begin{array}{l}\text { 3) Only few students answered the questions and } \\
\text { gave opinion from the teacher's statement. The } \\
\text { other students were talking with their friends } \\
\text { and some others seemed sleepy. }\end{array}$ & $\begin{array}{l}\text { 3) Some students gave opinion voluntarily. } \\
\text { The other students actively asked } \\
\text { something related to the lesson. }\end{array}$ \\
\hline
\end{tabular}

Students speaking skill could be improved by implementing video dubbing. There were some procedures which conducted in order to make improvement. The first step is video watching session which has goal to give students example of grammatical sentences and train them from native 
pronunciation and fluency. The second step was video discussion which the purposes are to make students analyze and develop the content and get various vocabularies. Video group presentation as the third step is aimed to train students' pronunciation and fluency.

The next step which is called as individual scenario composing has objective to let students develop the content from what they get from the previous activities (vocabulary and content from discussion). Video recording session (post test) is done after every student has the training session. The goal of this last step is to train students' pronunciation and fluency. The procedures involved some activities which were used to improve the students' interest towards English lesson.

"The qualitative findings imply that video dubbing projects are an effective means to improving pronunciation and intonation in several ways: (1) Film dubbing helps learners to reduce mispronunciation, (2) Learners improved in fluency by doing the projects, (3) It helps learners raise awareness of intonation, (4) Learners linked the pronunciation textbook with the actual use, (5) Film dubbing meets learners' perceptions (Chiu, 2012).

The activities of video dubbing could improve students' attitude. During the video discussion and video group presentation, students were expected to make the grammatical, comprehensible, and cohesive text by doing correction from one to the other group members. The innovative and interesting technique which is used in the class was welcomed well by students with their improvement of attitude from ignoring to paying attention. 
Since the technique was innovative, students were very enthusiastic to do all of the activities related to video dubbing. Video which is used as the main material for this technique successfully made students pay more attention and directly comment what they saw in it. In the end also known that students' speaking skill could be improved by the activities of video dubbing. The emphasis point is the use of video which is familiar as the interesting media in learning English. There were twe - zasons of using video as a teaching technique stated by Berk (2009: 2).

“(1) Grab students' attention, (2) Focus students' concentration, (3) Generate interest in class, (4) Create a sense of anticipation, (5) Energize or relax students for learning exercise, (6) Draw on students' imagination, (7) Improve attitudes toward content and learning, (8) Build a connection with other students and instructor, (9) Increase memory of content, (10) Increase understanding, (11) Foster creativity, (12) Stimulate the flow of ideas, (13) Foster deeper learning, (14) Provide an opportunity for freedom of expression, (15) Serve as a vehicle for collaboration, (16) Inspire and motivate students, (17) Make learning fun, (18) Set an appropriate mood or tone, (19) Decrease anxiety and tension on scary topics, and (20) Create memorable visual images".

By analyzing the research findings and according to the experts' theories, I conclude that video dubbing was effective to be implemented in English lesson to improve students' speaking skill.

During implementation, the use of video dubbing has strengths and weaknesses related to the teaching and learning process. There are some strengths of using video dubbing. Exactly, I had six strengths of it. The strengths were: (1) 
students had higher participation in the teaching and learning activity than before implementing the action, (2) students were very enthusiastic to the lesson since the use of such technology was new and innovative, (3) students could produce speech with grammatical sentence, various vocabularies, comprehensible content, stable speed, and right pronunciation, (4) all aspects of students' speaking skill had been improved, (5) students could easily catch important points of a material that was better than before implementing the action, and (6) students' achievement improved as stated in table 3.

Nevertheless, the use of video dubbing also has several weaknesses related to the technical practice and the students' result. The first problem comes from the students' result. Although students had practiced their text a lot, some of them still produced some mispronunciations in several English words. However, the frequency was lower than the implementation in the cycle 1 moreover from the pre research. The second weakness comes from the technical practice. Some students are still awkward in using VD as one of technology-based English learning technique. In short, teacher should give help and guidance more intensely to those students.

\section{CONCLUSION}

I found some research findings to answer the problem statements after holding the classroom action research to improve the students' speaking skill by video dubbing at the first grade students of SMA N Kebakkramat Karanganyar in the academic year 2013/2014. 
The conclusion of my classroom action research is the use of video dubbing can be used to improve students speaking skill. The achievement can be seen by the score improvement from test to test as stated in table 3 . There is also better improvement in classroom situation during the learning process. Students pay more attention to the teacher from cycle to cycle. They are active enough in answering my questions and giving opinion towards the explanation and the tasks from me. They are very interested and enthusiastic in learning process especially during the dubbing process because that was their first experience in English learning using technology.

The steps of video dubbing technique procedure support students speaking skill improvement. Those are: (1) Video Watching Session; in this session, students watched the video carefully which in some important parts were paused to practice their pronunciation like a native, (2) Video Discussion; students have a group discussion about the video an its components for the basic of the arrangement of new scenario, (3) Video Group Presentation; students group presented their result of discussion while the other groups gave comments to the presenting group in order to make the students be active in learning process, (4) Individual Scenario Composing; from the group discussion and group presentation, students composed new scenario individually which could be consulted first, and (5) Video Recording Session (Post test); students recorded their voice through headset into the computer and the result used as test score.

During the implementation of video dubbing, there are also some strengths and weaknesses faced. Those are about the students' improvements and the 
technical problems. There are several strengths in using video dubbing which are related to the students' positive improvements in the learning process. Those are like students having higher participation, being very enthusiastic to the lesson, being able to produce speech with grammatical sentence, various vocabularies, comprehensible content, stable speed, and right pronunciation, improving of all of speaking skill indicators, getting the better understanding of a material, and increasing speaking achievement from test to test as stated in table 2 .

Nevertheless, video dubbing also has a weakness during the implementation. Firstly, although students have practiced a lot, some of them still did mispronunciations in a very little frequency. Secondly, some students are still awkward in using VD as one of technology-based English learning technique. In short, teacher should give help and guidance more intensely to those students.

As suggestion for further research, other researcher could focus on the other skills like listening, reading, and writing or on the attitude improvement such as motivation, participation, and so on.

\section{REFFERENCES}

Arifin, Alwi. (2012). Penetapan Kriteria Ketuntasan Minimal: Sosialisasi KTSP. Retrieved from http://www.slideshare.net/alwiarifin/penetapan-kkm15084571 .

Arikunto, Suharsimi. (2007). Penelitian Tindakan Kelas (PTK) untuk Guru, Kepala Sekolah, Pengawas, dan Penilai. Yogyakarta: Universitas Negeri Yogyakarta. 
Berk, Ronald A. (2009). Multimedia Teaching with Video Clips: TV, Movies, YouTube, and $\mathrm{mtvU}$ in the College Classroom. International Journal of Technology in Teaching and Learning. 5(1), 1-21.

Boumova, Viera. (2008). Traditional vs. Modern Teaching Methods: Advantages and Disadvantages of Each. Master's Diploma Thesis. Masaryk University, Faculty of Arts.

Burston, Jack. (2005). Video Dubbing Projects in the Foreign Language Curriculum. CALICO Journal, 23 (1), p-p 79-92.

Chiu, Yi-Hui. (2012). Can Film Dubbing Projects Facilitate EFL Learners' Acquisition of English Pronunciation. British Journal of Educational Tecnnology, 43 (1), e24-e27.

Glaser, Barney G. (2008). The Constant Comparative Method of Qualitative Analysis. International Journal Grounded Theory Review 7 (3). Retrieved from http://groundedtheoryreview.com/2008/11/29/theconstant-comparative-method-of-qualitative-analysis- $1 /$.

Herminda. (2013). The Effectiveness of Using Story Telling Technique to Improve Speaking Ability of Second Year Students at SMPN 1 Boyolangu, Tulungagung. Thesis. Malang: Islamic University of Malang.

Jaggi, Seema. (No Year). Descriptive Statistics and Exploratory Data Analysis. New Delhi: Library Avenue.

Kayi, Hayriye. (2006). Teaching speaking: Activities to Promote Speaking in a Second Language. The Internet TESL Journal, 12 (11). Retrieved from http://iteslj.org/Articles/Kayi-TeachingSpeaking. html. 
Kemmis, Stephen and Robin McTaggart. (2007). Participatory Action Research: Communicative Action and the Public Sphere. Retrieved from http://www.corwin.com/upm-data/21157_Chapter_10.pdf.

Koshy, Valsa. (2005). Action Research for Improving Practice: A practical Guide. London: Paul Chapman Publishing.

Mettetal, Gwynn. (2001). The What, Why and How of Classroom Action Research. The Journal of Scholarship of Teaching and Learning. 2 (1).

Smith, Anne. (2005). Speaking is no Small Task. Retrieved from http://www.stutteringhelp.org/speaking-no-small-task.

Winarko, Heri. (2012, February 1st). Retrieved from Traditional Teaching Method vs. Now! website, http://heriwinarko21.blogspot.com/2012/02/ traditional-teaching-method-vs-now.html. 